Vol. 14, $n^{\circ} 2 \mid 2010$

Varia

\title{
Urban Heroes versus Folk Devils: Civilian Self- Defence in London (1880-1914)
}

\section{Emelyne Godfrey}

\section{(2) OpenEdition \\ 1 Journals}

Electronic version

URL: https://journals.openedition.org/chs/1185

DOI: $10.4000 /$ chs. 1185

ISSN: 1663-4837

Publisher

Librairie Droz

Printed version

Date of publication: 1 December 2010

Number of pages: 5-30

ISBN: 978-2-600-01470-0

ISSN: 1422-0857

\section{Electronic reference}

Emelyne Godfrey, "Urban Heroes versus Folk Devils: Civilian Self-Defence in London (1880-1914)", Crime, Histoire \& Sociétés / Crime, History \& Societies [Online], Vol. 14, n² | 2010, Online since 01

December 2013, connection on 22 March 2022. URL: http://journals.openedition.org/chs/1185 ; DOI: https://doi.org/10.4000/chs.1185 


\title{
Urban Heroes versus Folk Devils: Civilian Self-Defence in London (1880-1914)
}

\author{
Emelyne Godfrey ${ }^{1}$
}

\begin{abstract}
Cet article examine les réponses au problème de la violence des rues à Londres à la fin du XIX siècle et jusqu'en 1914, non du point de vue habituel des représentants de la loi ou des policiers, mais de celui du piéton masculin appartenant à la classe moyenne. Mon argument est que si les civils étaient bien munis d'armes «de ville», leur usage n'était pas universel ni incontesté, dès lors que l'exhibition de la violence masculine faisait l'objet de condamnations croissantes. L'examen des productions culturelles montre que l'on encourageait plutôt une riposte la moins agressive possible face à la violence interpersonnelle. Les réponses mesurées vis-à-vis de la criminalité de rue violente, adoptées par un nombre croissant de membres dynamiques des classes moyennes urbaines, montre également que le thème de la menace physique fournissait une occasion d'exprimer une forme d'héroüsme qui leur était propre, au tournant du siècle. En outre, l'expansion du monde des arts martiaux avait pour effet non seulement de conforter la masculinité «britannique» traditionnelle, mais aussi d'ouvrir la voie à la formulation et à l'acceptation d'identités alternatives.
\end{abstract}

This article considers the response to the problem of street violence in London in the late-nineteenth century and prior to 1914, not from the usual viewpoint of law enforcers or the police, but from that of the middle-class male pedestrian. It will be argued that while street weapons were carried by civilians, their use was neither universal nor unchallenged, especially as displays of violent masculinity were increasingly condemned. An examination of cultural sources indicates that minimally aggressive responses to interpersonal violence were actively promoted. The measured responses taken by a growing number of enterprising individuals in the middling classes towards violent crime on the streets also show how the theme of physical threat offered a site for the expression of urban, middle-class heroism at the turn of the century. Furthermore, the flourishing martial arts scene not only bolstered traditional 'British' masculinity but opened the way for the articulation and acceptance of alternative identities.

\footnotetext{
Emelyne Godfrey completed her doctoral thesis at Birkbeck College, London in 2008, entitled: The Self-Defence Scenario and Middle-Class Physical Prowess in English Literature, 1851-1914. She works as an independent researcher and some of her most recent publications include entries on sports for The Dictionary of Nineteenth-Century Journalism (British Library/Academia Press, 2009); a news piece entitled 'Sherlock Holmes and the Mystery of Baritsu' (May, 2009) and a feature on the garotting panics, 'Stranglehold on Victorian Society' (July, 2009) both published in History Today. A biography which she recently co-wrote with John Jackson, Chairman of History Today, entitled The Diaries of Alphabet Harrison is forthcoming in 2010. Emelyne Godfrey is also the Publicity Officer for the H.G. Wells Society.
} 


\section{INTRODUCTION}

The publication of Arthur Conan Doyle's 'The Adventure of the Empty House' (1903; hereafter AEH) coincided with the increasing movement against the use of offensive weapons and the development of martial arts in Britain. In 'AEH', Doyle not only recounts Sherlock Holmes's resurrection from his supposed death at the Reichenbach Falls, but also describes his defeat of Professor Moriarty's bastardly associate, Colonel Moran. Martin Wiener has promoted the use of literature alongside other sources for the purpose of studying nineteenth-century crime, arguing that 'the cultural imagination of great crimes offers historians rich texts for interpretation'2. The Sherlock Holmes canon and AEH in particular is not only inspired by and reflects contemporary crimes and methods of detection but was also directly influenced by trends in urban self-defence and, together with textual and material sources, is pertinent to an analysis of the shift in attitudes to the limits of violence and what constituted acceptable methods of self-defence.

This article responds to Martin Wiener's important study, Men of Blood, and seeks to build on his work on the 'civilizing offensive' as it related to attitudes towards personal protection. There is much to say on the proliferation of women's self-defence during the 1900s; however, due to space constraints, I have focussed on exploring the masculine response to street violence. As Wiener demonstrates, throughout the nineteenth century property crimes were treated more leniently than previously while acts of violence, particularly those committed by men, were increasingly harshly punished. The growing interest in personal protection from the late-Victorian era onwards coincided curiously with what Clive Emsley has observed as a downturn in the reported cases of violence and theft, most notably homicide, from the 1850 s until well into the twentieth century ${ }^{3}$. However, an apprehension of violence, committed by the inhabitants of what Dr Watson terms the 'dark jungle of criminal London'4 remained. At the same time, concerns over and interest in the tension between civilisation and aggression were manifested in a growing cultural obsession at the fin de siècle with the figure of the gentleman-villain. R. L. Stevenson's The Strange Case of Dr Jekyll and Mr Hyde (1885) is one of the most famous examples of novels and plays in which the respectable man with a dark side played a dominant role. The gentleman-villain also featured in bestsellers such as the Holmes adventures, Marie Corelli's The Sorrows of Satan (1895), and The Prisoner of Zenda (1894) by Anthony Hope. This fascination with the darker side of the civilized exterior was likely informed by shifts in attitudes towards crime and criminals so that the focus shifted from linking whole classes to particular crimes to studying individual cases 5 .

Wiener has classified nineteenth-century manliness in terms of the 'man of blood', who could be the gentleman-villain of melodrama or the violent criminal, and the violence-averse 'reasonable man', who was resolved on 'exercising greater restraint and settling more disputes non-violently ${ }^{6}$. This dichotomy is useful in

\footnotetext{
Wiener (2001, p. 2).

Emsley (2005, p. 32).

Doyle (AEH, p. 488).

Emsley (2005, p. 76).

Wiener (2004, p. 289).
} 
interpreting attitudes that informed the public imagination. However, Wiener's dichotomy does not take into account other masculinities and a study of attitudes towards self-defence tells us that there was a third type, which I will call the 'assertive' model. As this article will demonstrate, this model of middle-class masculinity was restrained by the ethos of the civilizing offensive but at the same time informed by turn-of-the-century interpretations of traditional forms of male gallantry. Furthermore, this new culture of self-defence offered a way of negotiating the tension between self-restraint and violence.

\section{CRIME AND THE CITY}

The way in which the rapidly expanding city was imagined influenced perceptions of the self, and informed attitudes towards physical threat. At the turn of the century, over 1 million pedestrians, including employers, employees (both female and male) and visitors, entered the City of London on a daily basis ${ }^{7}$, forcing commuters into packed spaces. As Georg Simmel observed in Metropolis and Mental Life (1903), for the city-goer, emotions must be switched off in order to comprehend the hectic surroundings, forcing an 'intellectualism of existence'. Amid the jostle, the pedestrian shrinks into himself and there is no room for individuality, only reserve. However, behind the eyes of the commuter lies the emotional need for selfdifferentiation, to stand out from the crowd. At the same time, Simmel argues that the façade of indifference masked anxiety: 'The inner side of this external reserve is not only indifference but more frequently than we believe, it is a slight aversion, a mutual strangeness and repulsion which, in a close contact which has arisen any way whatever, can break out into hatred and conflict' ${ }^{8}$. The daily commute was represented as a potentially perilous journey in which 'all the murderers, forgers, embezzlers, and assaulters whose crimes escape[d] detection altogether...[elbowed respectable passers-by] about in the streets of this and other towns every day of [their] lives ${ }^{\prime 9}$. The British garotting panics of the 1850 s and early $1860 \mathrm{~s}^{10}$ had predominantly been the culmination of fears over personal security in an urban context and were expressed in the manufacture of fanciful street weaponry as well as the toughening of punishments for crimes with robbery with strangulation. Richard Sennett has argued that the fear of violence was woven into the structure of the modern city, in the building of walls, roads and safe havens ${ }^{11}$. Yet, various late-Victorian crime panics showed that these boundaries could be traversed by criminals. Spates of armed burglaries during this decade suggested that suburban householders were not safe from the dangers of the criminal classes while the further dynamite attacks of the 1880s gave force to the idea of an ever-present physical danger, which literally ripped through the walls of Victoria Station and Scotland Yard.

\footnotetext{
White (2008, p. 16).

Simmel (1903, p. 331).

Gilbert (1871).

10 The American garotting panics merit further research. See diary entry on the New York garotting panic, dated 1 February 1857 in Taylor (2000, p. 73). 'Since the garrotte epidemic broke out, we have heard a good many reports of remarkable cases of that special amusement of the New York scoundrels', New York Times, 11 February 1857, p. 4.

11 Sennett (1991, p. xii).
} 
Charles Booth's investigation into the social composition of the metropolis and the striking visual maps which resulted from his findings had shown that there were pockets of poverty in even the wealthiest areas of London; however, the imaginary boundary drawn between East and West in the popular consciousness persisted. As Jack London learnt to his surprise, the tour company Thomas Cook's could take him to Africa or the Far East, but the East End remained a mystery ${ }^{12}$. During the Whitechapel Murders of autumn 1888, residents of West London were concerned about catching the omnibus - there were easy connections from Kensington to Whitechapel which broke down that 'wall' that divided London - in case they found themselves in Whitechapel ${ }^{13}$. The ghastly nature of the murders was accented by the fact that murder rates were falling and Britain was perceived to be becoming more civilized: 'It cannot but be a deep humiliation to every Londoner who has heretofore taken a just pride in the many evidences of a high civilisation abounding in the English capital to recognise the terrible fact that murder after murder can be perpetrated in our very midst, so to speak, undetected and unpunished ${ }^{14}$. There were limits as to how quickly the police could respond to violent crime in the streets. Forced to run to destinations and without the use of a siren, police response was in general slow, and, as with the garotting panics, officers arrived on the scene long after the offence had already been committed. In response, the Star issued a call to civilians: 'Up, citizens, then, and do your own police work !' ${ }^{15}$ The murders inspired the formation of local watch patrols such as that run by Toynbee Hall volunteers in the East End, with the purpose of protecting residents and catching the killer.

\section{FIREARMS AT THE FIN DE SIÈCLE}

For Sennett, 'the fear of exposure' (which he defines as a horror of injury) leads to 'a militarized conception of everyday experience as though attack-and-defense is as apt a model of subjective life as it is of warfare ${ }^{16}$. Sennett's 'attack-and-defense' dynamic was readily discernible in the design of what I argue constituted nineteenth-century 'body armour', used during the garotting panics discussed below. When the city and its facilities were perceived to be insufficient, weapons psychologically walled in civilians, protecting them from violent attackers. A wave of burglaries in the 1880s contributed to weapons, particularly firearms, becoming fashion accessories. Indeed, according to The Times, civilians ${ }^{17}$ of all classes were now carrying firearms and a veritable fashion was set with the result that 'a revolver [became] as necessary a companion as an umbrella ${ }^{18}$. It is not known how many guns were kept in Britain, but by the second half of the Victorian era, guns 'were reasonably accessible to everybody ${ }^{19}$. According to a Parliamentary debate,

\footnotetext{
Dennis on London (2008, p. 43).

Walkowitz (1992, p. 221).

Daily Telegraph, 1 October 1888.

Star, 8 September 1888.

Sennett (1991, p. xii).

Civilian men - women also carried firearms (Royal Armouries, Leeds).

The Times, 26 January 1885.

Wilkinson (2002, p. 235).
} 
firearms injuries 'were to be counted by hundreds' ${ }^{20}$. One image of the Black Museum which appeared in the Illustrated London News at the turn of the century shows an array of firearms of varying sizes, suggesting that there was an abundance of such weapons ${ }^{21}$.

The Sherlock Holmes canon is replete with a plethora of weapons, either everyday objects adapted for defence and attack or purpose-built articles such as knuckledusters and cudgels. As weapons historian, Lewis Winant, commented in 1955: 'Knife pistols and cane guns belong to our fathers' and grandfathers' days' ${ }^{22}$. Weapons included the combination six-shot revolver, knife and knuckleduster from 1890 , manufactured by the Belgian firm, Dolne ${ }^{23}$ and purchased by wealthier middle-class customers, often whilst abroad in the two major manufacturing countries of combination weapons, France and Belgium ${ }^{24}$. Other bizarre devices available in Britain included the Frankenau combination pocket book and revolver and the knife pistol by a successful British knife company, Unwin and Rodgers ${ }^{25}$. Catherine Dike's lavishly illustrated history of novelty, multifunctional walking-sticks, Cane Curiosa: From Gun to Gadget (1983), shows that gun-canes as well as swordsticks were in abundance in the late-Victorian era. These items could be purchased at James Smith, the New Oxford Street emporium, which has retained its original frontage, advertising 'sword sticks' and 'dagger canes', constituting a marker of the attitudes towards urban danger taken by past inhabitants of London.

Firearms historians concur that firearms were 'plentifully available' and that attempts to restrict the age of ownership and size of weapons met with limited suc$\operatorname{cess}^{26}$. True control did not begin until the Firearms Act of 1920, passed in the wake of the First World War in which more weapons had become available to ex-soldiers. As Malcolm has argued in her oft-quoted book: 'The nineteenth century ended with firearms plentifully available while rates of armed crime had been declining and were to reach a record low. Even those prone to magnify crime were struck throughout the century by the low level of violence, ${ }^{27}$. Malcolm quotes a nineteenth-century lawyer, James Paterson, who argued that 'the right of each to carry arms [...] and these the best and the sharpest [...] for his own protection in case of extremity, is a right of nature indelible and irrepressible, and the more it is sought to be repressed, the more it will recur' ${ }^{28}$. The case law in this area is summarised in the $R v R_{0 s} e^{29}$ of 1884 when Lopes $\mathbf{J}$ stated that 'homicide is excusable if a person takes away the life of another in defending himself, if the fatal blow which takes away life is necessary for his preservation ... [or] for the preservation of life [of another]'. However, the perpetrator can only avail of this defence if he 'acted without vindictive feeling' and at the time honestly believed (and had reasonable grounds for such belief), that life

\footnotetext{
20 Hansard, 'Pistols Bill', Parliamentary Papers, 27 February 1895, column 1658.

21 Wilkinson (2002, p. 168).

22 Winant (1955, p. 122).

23 These weapons are kept at the Royal Armouries, Leeds.

24 I am indebted to Mark Murray-Flutter of the Royal Armouries, Leeds, for this information.

25 Winant (1955, p. 157).

26 Wilkinson (2002, p. 235), Malcolm (2002, pp. 115-132).

27 Malcolm (2002, p. 130).

28 Paterson (1877, p. 132).

29 R v Rose (1884) 15 Cox CC 540 (Assizes).
} 
was in imminent peril' and the act was 'absolutely necessary for the preservation... [of] life'. $R v$ Rose involved patricide, where the young male defendant was held to have committed excusable homicide on the ground of self-defence, when he shot his father who was attacking his mother. However, before coming to the conclusion that the law readily supported the use of firearms, it should be noted that in $R v$ Rose the victim was described by his employer as 'the strongest man he had ever seen' and the defendant was relatively weak, which may well have influenced the conclusion that the use of firearms was justifiable.

It is not the aim of this article to dispute whether or not gun ownership led to lower levels of violent crime but rather to emphasize the way in which, despite the legality of owning firearms, pro-gun stances were strongly countered. For example, while she uses Paterson's legal text, Malcolm does not include his later protest against the 'right' of civilians to be armed, his plea for 'an end to the barbaric habit' of carrying 'daggers and loaded arms' and his vision of a future society in which 'each individual, inspired with his confidence, ceases thereafter to think of anything beyond more peaceful weapons' ${ }^{30}$. The 1895 Pistols Bill aimed to bestow on the police powers of searching individuals suspected of possessing firearms and to restrict the purchase of cheap pistols by imposing a licence fee. Malcolm suggests that despite vociferous objections, the Bill was submitted to the House of Lords where it floundered. As Malcolm concludes: 'Even those prone to magnify crime were struck throughout the century by the low level of violence ${ }^{31}$. Yet, this merely downplays the important and growing movement against the use of offensive weapons. In 1885, an editorial in The Times announced that: 'An epidemic of revolvers and the violences attendant on the habit of carrying them has been ravaging the United Kingdom.' The Times editorial offers a strong critique of this cultural climate, written during a time when, as Wiener has argued, displays of masculine violence were increasingly condemned. As the editorial in The Times states, negative effects of the 'monstrous fashion' of carrying guns was the risk to children as well as the possibility of accidental injury to the owner. Rash individuals could precipitate violent outbreaks with the effect that 'a slight panic might produce a fusillade in the quietest street ${ }^{32}$. Furthermore, the private member, the Marquess of Carmarthen, was influenced by press cuttings he had collected on firearms injuries and was moved to introduce the Pistols Bill in 1895 and told the House that judges, coroners and juries were sympathetic to his cause ${ }^{33}$.

Firearms were directly linked to acts of terrorism and burglary. An article in The Times lists the components of an unexploded device, believed to have been deposited by Fenian bombers in a portmanteau at Ludgate-hill Station: 'A tin box containing an American clock, with a pistol attached to the back of the clock, a cake and three-quarters of Atlas powder; ten detonators were stuck into the cakes which were in the tin, and one in front of the muzzle of the pistol ${ }^{34}$. In a set of features on

30 Paterson (1877, p. 442). Paterson aimed to make English law accessible to larger numbers of educated readers.

31 Malcolm (2002, p. 130).

32 The Times, 26 January 1885.

33 Hansard, 'Pistols Bill', Parliamentary Papers, 27 February 1895, column 1657.

34 The Times, 10 March 1885. Manufactured in America, Atlas Powder was a modified and less volatile form of dynamite: 'Atlas Powder [...] has a rather unenviable reputation in England, due to its having been the explosive used in the outrages which were committed in London a few years ago by 


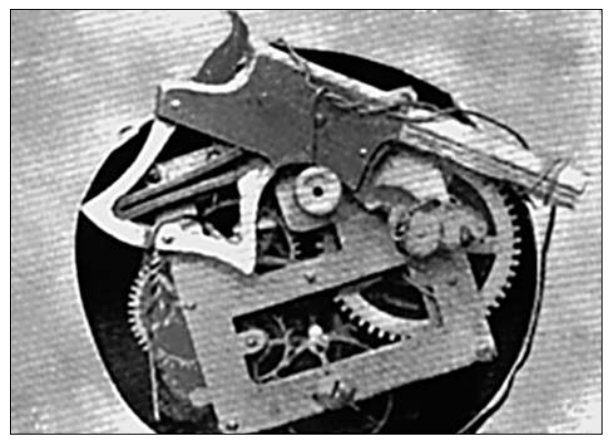

Figure 1: Anonymous, Dynamiters (1894, p. 126).

the weapons kept in Scotland Yard, the Strand included a photograph of a similar clockwork machine which failed to detonate at Paddington Station ${ }^{35}$ (Figure 1). The pistol which formed part of the device is clearly visible and implies that while firearms could kill individuals, when wired into a particular contraption they could injure or maim countless numbers of commuters and pedestrians. As Wilkinson says, "it may well be that the growth of violence engendered by the actions of Irish terrorists, the Dynamiters and Fenians, created a stronger impression of fear' and 'may have caused those in power to view the ownership of arms by the public as a potential threat ${ }^{36}$, and consequently give bad press to firearms. The Strand also featured an article on the firearms used in burglaries, referring to specific crimes in which pistols and other weapons were used in the 1880s ${ }^{37}$ Having seen the 'interesting collection of burglars' weapons' at Scotland Yard, the Undersecretary for the Home Department, George Russell, was convinced that 'the use of pistols by that class of criminals was largely on the increase ${ }^{38}$.

Debates ensued over whether police officers should be armed with handguns. According to Wilkinson: 'When armed crime apparently flared in the 1880s there were indications that the public would prefer to see the police armed rather than trying to stop people acquiring firearms' ${ }^{39}$. Punch displayed many cartoons of policemen insufficiently equipped to deal with violence. 'An Unequal Match' depicts a housebreaker pointing a revolver at the policeman who is armed only with a truncheon $^{40}$. In 1889, Mr Punch lectures three police officers: 'Now, my fine fellows, this is how I should like to see you, armed, hunting in threes; you'll be even with the rascals, and then a taste of this will finish the scare as it did Garrotting ${ }^{41}$. Officers

the so-called dynamiters.' Eissler (1890, p. 45). I thank Stuart Ivinson and Richard Jones of the Royal Armouries, Leeds, for their helpful suggestions.

35 Anonymous, Dynamiters (1894, p. 126). Figure 1.

36 Wilkinson (2002, p. 235).

37 Anonymous, Burgling (1894, pp. 279-280).

38 Hansard, 'Pistols Bill', Parliamentary Papers, 27 February 1895, column 1667.

39 Wilkinson (2002, p. 233).

40 Punch, 8 October 1881.

41 Punch, 19 January, 1889. 
on night beats in London's suburbs - where burglary appears to have been more likely - were equipped with firearms ${ }^{42}$ although support for their use was contested within the force. Despite the persuasions of Mr Punch's satire, only fifty percent of officers based in the outskirts of London voted to be equipped with firearms ${ }^{43}$. Senior policemen discouraged the junior ranks from applying for guns and while some officers did train, only two thirds of these went on to bear arms on their beats. Even those who did, were often disinclined to use them and, in any case, they were only permitted to use them for self-defence ${ }^{44}$.

In the Holmes stories published prior to 'AEH', Holmes does carry and use firearms. Peter Hitchens has argued that 'Sherlock Holmes frequently set out on his private missions with a revolver, as did his colleague, Dr Watson' and concludes that 'it is quite clear from the stories that the author expects his readers to think this is entirely normal and legal ${ }^{45}$. Holmes would have possessed a regulation firearm, the widely favoured Webley Metro-Police ${ }^{46}$. However, his use of firearms is infrequent and never disproportionate to the threat except when challenged by dart-wielding Tonga in 'The Sign of Four' (1890), a criminal with a life-preserver in 'The Adventure of the Beryl Coronet' (1892) and Moriarty in 'The Adventure of the Final Problem' (1893). In 'The Adventure of the Musgrave Ritual' (1893; hereafter AMR) the gun is used as a declaration of Holmes's support for his Queen and country. Watson describes how 'with his hair-trigger and a hundred Boxer cartridges' Holmes decorated the wall 'with a patriotic V.R. done in bullet-pocks' ${ }^{47}$. The scene in AMR is less a support for firearms than an indictment of regicide in which Holmes marks out his support for the Queen by employing a weapon often used to target the monarch. During the Boer War, Doyle expressed support for the creation of a rifle corps to defend British interests abroad although 'The Hound of the Baskervilles' (1901-02) warns against the use of firearms for individual self-defence. When Watson chases a man across the moor who he believes is a convict, he desists from using his pistol: 'I had brought it only to defend myself if attacked, and not to shoot an unarmed man who was running away' ${ }^{48}$. Here, Watson measures manliness by his awareness of appropriate self-defence. In addition, this scene emphasizes the perils of using firearms as the fleeing man was indeed a convict but could have been Holmes who was also exploring the moor.

The incursion of street dangers in the domestic milieu is emphasized in AEH when Ronald Adair is killed in his home by a bullet which was mysteriously fired into his room. The murder scene is reminiscent of the killing of Mary Kelly, the last of the five canonical victims of Jack the Ripper. Adair's face is badly mutilated by a weapon of which there is no trace:

His head had been horribly mutilated by an expanding revolver bullet, but no weapon of any sort was to be found in the room [...]. No one had heard a shot. And yet there was the dead man, and there the revolver bullet, which had mush-

\footnotetext{
42 Emsley (2005, p. 129).

43 Wilkinson (2002, p. 168).

44 Emsley (1985, pp. 125-149).

45 Hitchens (2003, p. 149).

46 Torrese (1992, p. 156).

47 Doyle, AMR, p. 386.

48 Doyle, THB, p. 725.
} 
roomed out, as soft-nosed bullets will, and so inflicted a wound which must have caused instantaneous death ${ }^{49}$.

Adair's killer, Colonel Moran, formerly of Her Majesty's Indian Army, also targets 221B Baker Street, shooting what he believes is Holmes but which is, in fact, a wax effigy, left by the detective to fool Moran. Adair's grisly death reminds the reader what might have happened to Holmes in his domestic sanctum; however, Holmes has his revenge. Unknown to Moran, Holmes and Watson creep up behind him while he waits at the window of the empty house opposite 221B, preparing to aim. After grappling with Moran, Holmes and Watson hand the colonel over to the police.

As Holmes learns, the weapon Moran uses to murder Adair is an airgun, a weapon of stealth, cunningly adapted by a malevolent German scientist, employed by Holmes's nemesis, the arch-criminal, Professor Moriarty, to contain the controversial soft-nosed 'dum-dum' bullet. These projectiles explode inside the body, leaving a ghastly exit wound. They were outlawed at the Hague Convention in 1899, although the British delegation, together with the representatives of the United States and Portugal (which abstained), did not sign Declaration VI, which related to the forbearance of the use of such expanding bullets ${ }^{50}$. Doyle was appalled by the use of these bullets by the British army against 'white races' during the Boer War ${ }^{51}$. He was possibly expressing the gravity of this offence to the general public when he had Holmes, who was practically a national hero, stalked by a killer armed with dum-dums. Moran embodies what Wiener has termed the violent 'empire man', the imperial equivalent of the man of blood. By contrast, Holmes represents the assertive home Englishman who is nevertheless ready to fight using his body and intellect against homeward-bound criminals. Moran's sentinel, Parker, is a 'garroter by trade, ${ }^{52}$. What permeated these widely held comments was a nightmarish vision of exiled masculinities returning with a vengeance. In a poignant manner, Holmes's victory over his imperial rival and his lowly garotter-associate is signalled by the relegation of Moran's airgun to Scotland Yard's Black Museum, thereby transforming what was formerly a threat to the nation into a mere museum curiosity.

\section{HOOLIGANS AND URBAN GLADIATORS}

The fascination with self-defence using the body and everyday items was not new to the 1890s. For instance, during the London Monster panic of the 1790s, the press lampooned women's attempts at personal protection from the Monster's knife by wearing copper bottoms ${ }^{53}$. In the early- to mid-nineteenth century, the prominent boxing journalist, Pierce Egan, wrote extensively on combat and self-defence. As John Strachan has recently shown, he shared a passion with his contemporaries, Lord Byron, J.H. Reynolds and Thomas Moore, for writing poetry inspired by the

\footnotetext{
49 Doyle, AEH, p. 484.

50 Eyffinger (1999, p. 426).

51 Dr Conan Doyle on his Defence, Daily News, 31 January 1902, in Gibson, Green (1986, p. 84).

52 Doyle, AEH, p. 490.

53 Bondeson (2002).
} 
boxing ring ${ }^{54}$. What distinguishes the 1890 s to the pre-war years is the rapid growth of interest in and increased availability of British and 'exotic' methods of responding to interpersonal violence using the minimum of force. Despite the title, Wiener's Men of Blood is more concerned with masculine restraint, emphasizing the legal and social consequences that followed expressions of passionate anger. This section argues that concerns over urban crime, 'hooliganism', stimulated a vibrant culture of self-defence which not only aimed to tackle the problem of street violence from ground-level but also negotiated the gap between the 'man of blood' and the 'reasonable man'. The figure of the flâneur features often in studies on city life and gender in the long nineteenth century and defined as an impartial spectator of urban life. However, the vast collection of literature on self-defence which was produced during this time shows how the city was not only observed but also experienced in a multi-sensory level and also raises the question as to how it is really possible to feel distanced from one's environment with the attendant risk of crime and physical danger.

Bartitsu's appearance was timely, following the 1898 August Bank Holiday in which the 'hooligan' was identified as a public threat. According to $P M G$ : 'The chief objects of the promoters [of Bartitsu] [...] is to provide a means whereby the higher classes of society may protect themselves from the attacks of Hooligans and their like all over the world ${ }^{55}$. As Geoffrey Pearson shows, these urban gangs were a new form of folk devil, descendants of the mid-Victorian garotter. While the hooligan may have been armed with clubs, knuckles, iron bars and leather belts, Pearson doubts that he carried firearms ${ }^{56}$ although the press did represent him as a threatening presence: 'When he attacks a man he frequently does so for the mere sake of injuring him. The police, of course are too often the victims of these desperados ${ }^{57}$. As Wood says, 'savagery brought clarity to the civilized identity ${ }^{\text {, }}$ and it is likely that the Hooligan scares promoted the expression of English gentlemanliness in response to violence of the lower classes. These scares also supported the growth of a burgeoning culture of 'British' self-defence which avoided the aggressive and increasingly unmanly action of using a firearm against an opponent equipped only with basic weapons, an approach which offered readers a method of asserting themselves in the face of the rascally violence against which the police officer might have struggled.

The culture of self-defence represented sheer masculine physical energy during a time of growing concern over the decline of the British Empire and the deleterious effects of civilization on the nation's health, a fear realised when the shocking physical condition of Boer War recruits was made apparent. The eminent Surgeon-Commandant of the Volunteer Medical Staff Corps, James Cantlie, warned his audience in 1885 that degeneration occurs when 'luxury in families or nations begets sloth in the unwise, and exercise of all kinds becomes to be considered vulgar ${ }^{59}$. He was concerned about the state of city dwellers, particularly Londoners, due to the poor

\footnotetext{
54 Strachan (2009, pp. 17-23).

55 Pall Mall Gazette, 23 October 1900.

56 Pearson (1983, p. 102).

$57 \quad$ Newcastle Weekly Courant, 22 July 1899.

58 Wood (2004, p. 33).

59 Cantlie (1885, p. 4).
} 
air quality in the metropolis. This problem was compounded by the over-reliance on modern machinery for labour and travel: 'Muscle now-a-days is at a discount; brain power is what is sought for [...] but as it requires a healthy heart to give forth a normal sound, so it requires a healthy brain to beget wise thoughts ${ }^{60}$. Cantlie looked to Rome and to Spain, arguing that decadent lifestyles had resulted in the demise of these once great international leaders. Concerns over the proliferation of 'effeminate', domesticated masculinity were, as Julie English Early has argued, reflected in contemporary novels, most notably those by George Gissing ${ }^{61}$. A few years later, in 'Zoological Retrogression', Gissing's friend, H. G. Wells, argued that the British Empire, let alone the human race, could not be complacent about being on an upward path. Wells argued that when the 'respectable citizen of the professional classes' becomes domesticated and tamed, his ambitions 'atrophy' and he 'lives an almost vegetative excrescence on the side of the street ${ }^{62}$. Wells's bleak conclusion was famously articulated in the futuristic dystopia presented in The Time Machine (1895) in which human society has been split so that the feeble, idle Eloi are haunted by the carnivorous Morlocks that prowl beneath their feet and occasionally come to the surface to claim a victim ${ }^{63}$. For Wells, a healthy individual also needed imagination and flair, a point which he expressed in The War of the Worlds, when he refers derisively to 'all those damn little clerks', wife-fearing, flabby workers, without 'spirit' who 'skedaddle' obediently to their workplaces in the metropolis ${ }^{64}$. Thus, despite being white, male and middle-class, the city worker, particularly the clerk, is too harassed and henpecked to be the top of the hegemonic masculine hierarchical order. While urban living offered opportunities, it could sap vital energy and, as Wells advises, the modern man should guard against such dangers.

Tom Brown's Schooldays is generally considered to represent popular notions of middle-class physical capability, promoting the idea that the English gentleman was expected to be able to defend himself with his fists if called on to do so, to 'speak up, and strike out if necessary for whatsoever is true and manly, and lovely, and of good report' ${ }^{65}$. As Dennis W. Allen argues, it is the middle-class body in the novel that symbolizes Englishness ${ }^{66}$. Quite possibly, Hughes attempted to redress the problem that, as Anthony Simpson has observed of the 1840s, 'instantaneous heroism' was not readily associated with the middle class ${ }^{67}$. Yet, concerns persisted over the middling man's ability to defend himself, a worry which was apparent in the sheer number of sensational press depictions during the garotting panics of mainly middleclass victims ${ }^{68}$. As the discussions on degeneration above illustrate, this fear had not abated by the end of the century. Furthermore, in his helpful survey of late-Victorian boxing, Stan Shipley has observed that while many boxing managers were middleclass, university graduates and army officers were not national champions and that

\footnotetext{
60 Cantlie (1885, p. 3).

${ }^{61}$ Cantlie (1885, p. 3).

62 Wells (1891) in Ledger, Luckhurst (2000, p. 9).

63 Wells (1891) in Ledger, Luckhurst (2000, p. 12).

64 Wells (1898, p. 148).

65 Hughes (1857), in Gay (1994, p. 105).

66 Allen (1994, pp. 114-132).

67 Simpson (1988, p. 108).

68 Godfrey (2008, pp. 61-63).
} 
the middle class did not appear to 'shine as exemplars of physical courage and endurance ${ }^{69}$.

As Wood tells us, bourgeois culture was based on self-restraint and passion 'was often linked directly to violence ${ }^{70}$. However, this does not consider the presence of masculinities based on the articulation of emotion. E. Anthony Rotundo has shown how American writers returned to nature in order to test modern physical manliness. Rotundo posits three models of middle-class manliness: the Masculine Achiever, the Masculine Gentleman and the Masculine Primitive. The last category 'asserted its power in the private writings of the middle class' in the 1860s and was a response to sedentary, bourgeois white-collar professional life. The rugged Wild West provided the inspiration for the formulation of such 'Primitive' masculinities based on physical strength and the capacity to survive. As Rotundo points out: 'Suddenly passions and impulses had become a valued part of a man's character' ${ }^{71}$. In the lateVictorian era, the press recast encounters with urban criminals as a tussle between the educated, courageous man and a wild beast, the battle between the 'civilized' and the 'savage'. Such imagery was not unique to the turn of the century. By way of illustration, garotters in the 1850s and 1860s had often been likened to tigers, 'specimens of the true Bengal breed ${ }^{72}$. Yet, the turn of the century, readers were offered a dizzying array of gladiatorial fantasies of gentleman versus criminal. Most famously, Holmes physically tackles his nemesis Moriarty who is often likened to a snake. Possibly influenced by lugubrious presentiments regarding the degeneration of the middle class, the popular periodicals, Sandow's Magazine and Health and Strength $(H S)$ were founded in the late 1890s and were consumed by readers of wealthy and more modest incomes respectively. They boasted fantastical images from the Roman amphitheatre, depicting male wrestlers using raw masculine energy to tackle wild animals. Frederick Lord Leighton's sculpture 'Athlete Wrestling with a Python' (1877) was copiously reprinted at the turn of the century, also appearing in the Strand shortly before AEH. The photograph of Leighton's statue visually encapsulates Holmes and Moriarty's struggle at the Reichenbach Falls as they become 'locked in each other's arms ${ }^{73}$. If the metropolis was a 'jungle', then Holmes's struggle with snake-like, round-shouldered Moriarty at the Reichenbach Falls was representative of the national fight that was raging against moral and physical atavism, against the destructive heart of darkness and the innate aggression of man. Like Leighton's serpent, Moriarty wraps his 'long arms ${ }^{74}$ around Holmes, but it is Holmes who, through his knowledge of the latest gentlemanly martial art, Bartitsu, is victorious.

In AEH, Holmes tells Watson that he defeated Moriarty and save himself by employing 'baritsu' ( $\mathrm{sic}$ ), which he refers to as 'the Japanese system of wrestling', a sport which he had already used on numerous occasions ${ }^{75}$. Baritsu has been the subject of much speculation among Holmes specialists. In 1997, Richard Bowen (1926-

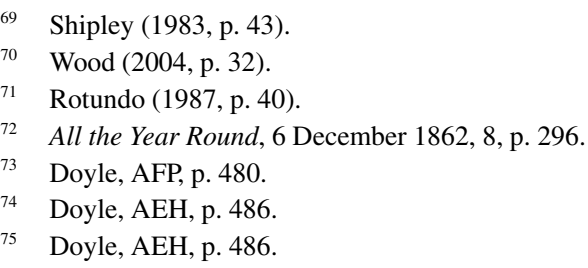


2005), the late President of the London Judo Budokwai, confirmed the mysterious sport as 'Bartitsu', an influential and real-life martial art founded by an Anglo-Scottish engineer, Edward William Barton-Wright (1860-1951) ${ }^{76}$. It is highly likely that the misspelling of Bartitsu, which appears as 'baritsu' in AEH, originated from an article from The Times of 1901 which describes the Japanese assistants who were "engaged to act as instructors at Mr Barton-Wright's school of physical culture in Shaftesbury Avenue, where the "Baritsu" system of self-defence [was] taught" ${ }^{77}$. That Doyle, an amateur sportsman and boxer, included the martial art in his adventure is a testament to Doyle's view that the martial art be better known by the general public. As the earlier Holmes adventures reflect the current trends in street weaponry, the stories also demonstrate what other means were popular at the time. The Bartitsu Club left a rich legacy, but its own fame was short-lived. By the time AEH appeared in the Strand in 1903, the club had already closed. Barton-Wright allegedly charged exorbitant fees and had no head for the minutiae of running a business, venturing into precarious waters by experimenting in electrotherapy which resulted in costly law suits from patients. As a result, the club was closed before 'baritsu' appeared in 'AEH'. The inventor of Bartitsu then found himself on hard times. In 1951, he was given a pauper's funeral and his name slid into insignificance.

Today, Barton-Wright is receiving renewed attention from martial arts historians, most notably, the world-renowned theatrical fight director, Tony Wolf, the recognised world expert on Bartitsu. The Royal Armouries, Leeds, has in recent years included Bartitsu demonstrations in its public performances and in 2009, the $150^{\text {th }}$ anniversary of Doyle's birth, Guy Ritchie's martial-arts-based interpretation of the Sherlock Holmes adventures, included Bartitsu-inspired fight choreography. Barton-Wright spearheaded the development of martial arts in Britain by attracting international experts to his London school. He had learnt jujitsu whilst on business in Japan in the 1880s, one of his instructors being Jigoro Kano who founded Kodokan judo in the same decade. The British public knew very little about Japanese martial arts at this time and, detecting a gap in the market, Barton-Wright travelled back to London and set up the Bartitsu Club in 1898.

Bartitsu was an amalgamation of jujitsu and English boxing. It was based on the principle of jujitsu, that is, of using the opponent's weight and size through the manipulation of pressure points. The first known promotion of Bartitsu appeared in 1899 in the form of two lengthy and generously illustrated articles, 'The New Art of Self Defence: How a Man may Defend Himself against every Form of Attack ${ }^{17}$, in Pearson's Magazine (hereafter PM), a periodical which was modelled on the Strand and was financially accessible to the middle classes on both sides of the Atlantic. $P M$ boasted articles on adventure, features on sport and remarkable fiction; it had just recently serialised H.G. Wells's The War of the Worlds (1897). Here, BartonWright offered the readers of $P M$ the opportunity to imagine their own responses in swashbuckling fantasy scenarios which, although statistically unlikely, could nevertheless occur in everyday life. The urban professional could claim his place at the top of the hierarchical chain by demonstrating physical and mental prowess and

\footnotetext{
76 Bowen (1997, pp. 22-26).

77 The Times, 23 August 1901.

78 This article was also adapted for the Chicago Daily Tribune, 2 April 1899.
} 
self-sufficiency, qualities which Tosh and Connell argue generally display betoken status in the hegemonic order ${ }^{79}$.

Barton-Wright presented his martial art as a form of self-defence to harmonise with the 'British' fight ethic. It was frequently asserted that the 'Britisher [...] is handy with his fists in an emergency' while the 'Italian, Greek, Portuguese, or South American give preference to the knife ${ }^{80}$. For Barton-Wright, British boxers 'scorn taking advantages of another man when he is down' but a foreigner might 'use a chair, or a beer bottle, or a knife' or, 'when a weapon is available' he might employ 'underhanded means, ${ }^{81}$. As Wiener points out, 'the use of knives was frequently to be described as not only unfair, but un-English (despite the ubiquity of knives, and the commonness of knife assaults) ${ }^{82}$. One self-defence manual argued that Britons 'live in a country where knife and revolver are not much in evidence' ${ }^{83}$. The historical value in this statement perhaps lies in it being an attempt to extol the 'British' virtues of boxing and a concomitant repugnance towards the use of weaponry. Therefore, while it was legal to carry weapons, for a growing number of critics, the most desirable condition was that in which citizens could traverse the streets minimally armed or completely unarmed. Furthermore, the views of Barton-Wright and his contemporaries that English Bartitsukas and martial artists alike are principled men is reflected in the Holmes canon, where Holmes never uses a knife although his enemies, whether foreign or British, do so at times. In 1895, Charles Hopwood, MP for Middleton, framed his objection to the Pistols Bill with a rhetorical question which suggests that even those who objected to anti-gun legislation had misgivings about the use of offensive weapons: 'If the use of dangerous weapons were to be prohibited, why not have an investigation in regard to knives? Why should a man be allowed to carry a dagger or stiletto, and not a revolver? ${ }^{84}$ Instead, Barton-Wright suggested manoeuvres for self-defence with overcoats, hats and sticks. [Figures 2 and 3]. By advocating minimal force using non-weapons, Barton-Wright positioned himself within the confines of the civilizing offensive.

Barton-Wright cultivated his image as a British fighter of crime and athletic artist through his sartorial choices and his appearance. If the late-Victorian scuttlers of Manchester donned bell-bottomed trousers, peaked caps and clogs to signal their group allegiance ${ }^{85}$, the Bartitsuka wore the uniform of the mat indoors; outdoors he donned only the sober clothing and items which gentlemen carried, although he used these to creative effect. Barton-Wright's 'new art' harmonised with the ideals of New Chivalry, a concept to which Doyle subscribed, in which homosocial activities played an important role. Recent research has emphasized men's involvement in matters regarding the domestic milieu ${ }^{86}$; however, Bartitsu symbolized the lateVictorian 'flight from domesticity' ${ }^{87}$. While Bartitsu was ideal for smaller individu-

79 Tosh in Connell (2004, pp. 41-60).

80 Newton (1910, p. 14) and Jewell (1904, p. 173).

81 Barton-Wright (1899b, p. 269).

82 Wiener (2004, p. 57).

83 Collingridge (1914, p. 9).

84 Hansard, 'Pistols Bill', Parliamentary Papers, 27 February 1895, column 1662.

85 Davies (1998, p. 353).

86 The 2008/9 Geffrye Museum exhibition, 'Choosing the Chintz', explored on men's involvement in the home since 1850 .

87 Tosh (1999). 


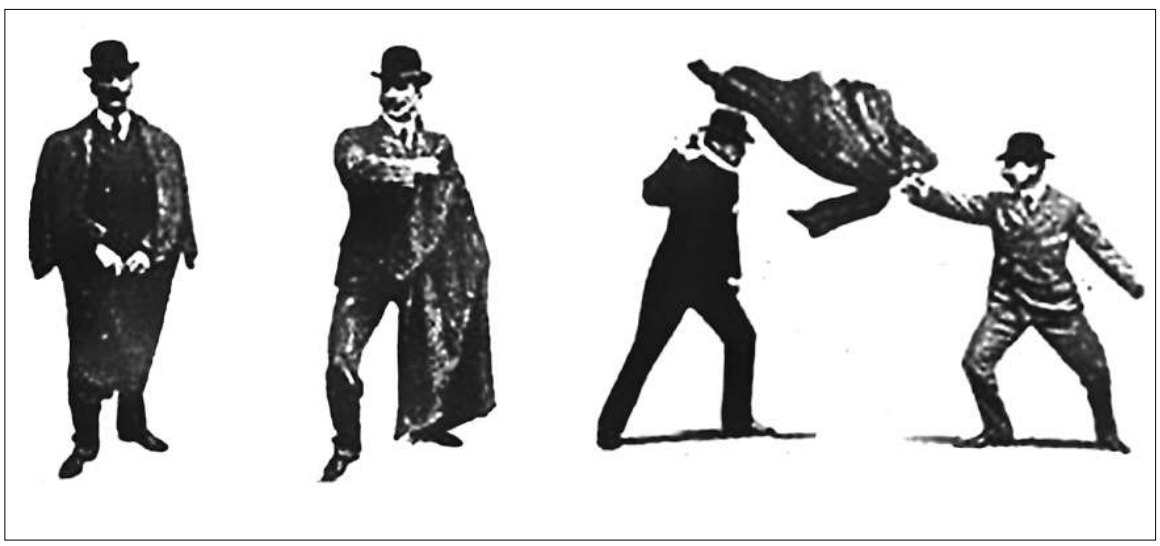

Figures 2 and 3: Barton-Wright (1899b, p. 296).

als and by inference, women - indeed, he is sometimes credited with bringing women's self-defence classes to Britain - it was overwhelmingly styled as a suave martial art for men. In an interview, Barton-Wright revealed that 'he found ladies a little - just a little - tiresome' as they 'expect to be taught for less because they are ladies' and 'think they will know things when they don't ${ }^{88}$. According to the interviewer, Barton-Wright taught 'an endless number' of ladies but it is likely that the price of the classes and the focus on teaching men may in reality have discouraged female students from applying. The presentational style of his martial art does reflect the preoccupation with the internal masculine self. At a time when self-help and industry were highly praised, Bartitsu represented an efficient use of leisure time. Barton-Wright took up jujitsu in Japan as a way of staving off lethargy: 'Men drink and lie about on club verandahs a great deal in the East, he didn't happen to find amusement in that ${ }^{\prime}{ }^{89}$. Bartitsu was more than a hobby: it represented masculine vigour. Indeed, Barton-Wright was clearly a showman and described manoeuvres for men of average strength including how to lift a chair carrying four men and how to maintain one's balance standing on one foot and whilst being pushed by an opponent ${ }^{90}$. Barton-Wright's articles feature men fighting either in twos or in groups and are devoid of photographs of women. When Barton-Wright is depicted demonstrating manoeuvres with fellow Englishmen, he always wears white and plays the part of the gallant Bartitsuka while the attacker is attired in darker clothing. The contrast between black and white was most likely fostered so that readers could more readily distinguish between the hero and the attacker, but such a choice is suggestive of the black-clad gentleman-villain in stage melodrama, a tactic employed by Doyle in AEH in which Moran is the malevolent, 'swarthy' gentleman-assassin. Thus, many of Barton-Wright's photographs constitute pictorial representations of conflict between the man of blood and the assertive, physically flamboyant practitioner of the defensive arts. At the same time, Barton-Wright pejoratively refers to his assis-

\footnotetext{
88 Nugent (1901, p. 338).

89 Nugent (1901, p. 338).

90 Barton-Wright (1899a, p. 59-61).
} 
tants as 'little Japs' as Connell says, 'the interplay of gender and other structures such as class and race creates further relationships between masculinities' ${ }^{91}$. BartonWright's choice of language and presentational style thus emphasizes his perceived placing in the masculine hierarchy.

Bartitsu was not completely non-violent and permitted expression of masculine strength, even legitimating acts of punishment, albeit along acceptable lines. Barton-Wright emphasizes that his sport gives the Bartitsu practitioner, otherwise known as a 'Bartitsuka', the power to injure. Barton-Wright says that 'if a policeman is holding a prisoner in a certain position, it is not necessary to break the man's arm to show his power [...]. So in these methods of self-defence when your opponent is once at your mercy he will cry "Hold!" long before you could seriously injure him ${ }^{, 92}$. Moreover, once an assailant has been defeated, he is 'then at the mercy of the man he has attacked, who can choose any part of his body on which to administer punishment ${ }^{\prime 93}$. However, as Wolf points out, some form of physical retaliation is necessary to keep the assailant from attacking anew ${ }^{94}$. Therefore, the attraction of Bartitsu is the exhilarating feeling of self-confidence and power over the attacker, the power to do injury but the 'manly' self-control to prevent committing such an action. Barton-Wright frames his martial art within the confines of what is culturally endorsed as constituting appropriate masculine assertiveness : 'We will suppose that you have to pass through a locality late at night where there is a likelihood of such an attack, and you do not wish to run the risk of bringing yourself within the law by relying upon a revolver' ${ }^{95}$. Indeed, in a manoeuvre to counter a knife attack, BartonWright recommends the use of a mere coat to stun the assailant ${ }^{96}$. The body itself could be a shield: 'A trained exponent, through practice, makes his throat so strong that it is quite impossible to throttle him, and he is, therefore, quite safe against garrotting' ${ }^{97}$. As regards Richard Sennett's conception of the urban 'attack-anddefense' response, methods devised by Barton-Wright set up walls between the attacker and the civilian using the minimum amount of force.

\section{THE INFLUENCE OF BARTITSU}

Bartitsu's appearance in the Holmes canon was part of a growing obsession with Japan, a development which was manifest in a plethora of printed material including magazines, most notably, the Strand, which boasted a large collection of articles on the supposed strangeness and majesty of Japanese culture. The idea of a smaller contender, Japan, succeeding against larger forces in the Russo-Japanese War of 1905 captured the public imagination: 'Every Jap is an athlete of a high order [...] the Japs, in addition to their superior physical condition, are possessed of a weapon, that in hand-to-hand struggle, would give them an enormous advantage over Euro-

\footnotetext{
Connell (2006, p. 80).

Barton-Wright (1899b, p. 270).

Barton-Wright (1901b, p. 132).

Tony Wolf, Interview, 13 June 2007.

Barton-Wright (1899b, p. 269).

Ibidem.

97 The Era, 20 October 1900.
} 
peans ${ }^{98}$. Against this backdrop, jujitsu enjoyed popularity and Barton-Wright's assistants, Yukio Tani and Sadakazu Uyenishi, who had toured with Barton-Wright across Britain, became influential instructors. Uyenishi taught Emily Watts, the first female jujitsuka, whose manual, The Fine Art of Jujutsu (1906) is the first known women's self-defence book in English, written by a woman. In this manner, BartonWright and his protégé, Uyenishi, directly influenced the development of women's self-defence training in Britain.

While Barton-Wright's promotional articles in $P M$ constituted self-help monographs, Uyenishi brought the opportunities of learning jujitsu to a larger market and promoted a link between British and Japanese cultures. After the closure of the Bartitsu Club, Uyenishi set up the School of Japanese Self-Defence at Piccadilly Circus, London. In print until 1956, The Text-Book of Ju Jutsu as Practised in Japan (1906) is addressed to the British amateur who is told that jujitsu is a 'developer of strength and muscle of the right quality'; a 'magnificent sport, game, or exercise' which promotes 'mental, moral, and physical qualities'99. Uyenishi expresses an interest in British supremacy, arguing that jujitsu is 'a matter of supreme and even National Importance' for Britain, presumably in the defence of the nation as well as the individual, reiterating the point that 'some knowledge' of Japanese culture could be vital to Britain's survival ${ }^{100}$. To demonstrate, Uyenishi uses a sequence of photographs, inspired by Eadweard Muybridge's technique in which a set of stills represented the actions of the human body in various stages through motion. Moreover, by aligning his self-presentation with Muybridge's style, Uyenishi emphasizes the physical dynamism of jujitsu: martial arts were not merely a response to a demand for tackling crime; they were a mode of self-articulation. As Tosh points out, 'hegemony invites challenge and contestation, as those whom it oppresses seek to topple it and to replace it with a differently ordered hegemony' ${ }^{101}$. Here, Uyenishi is no longer Barton-Wright's sidekick. His photographs are sensual, highlighting his taut musculature, demonstrating his own vision of masculinity through his virility and physical energy (also 'hegemonic' traits). [Figure 4].

In 1906, Uyenishi convincingly maintained that: 'All Britishers have at least heard of Ju-jutsu, while a vast and rapidly increasing number take a larger or smaller interest in the subject ' ${ }^{102}$. Uyenishi and Tani's schools also appear frequently in $H S$ 's advertisements alongside features on mixed martial arts contests in which boxing and jujitsu were enthusiastically compared. Numerous articles showed how martial arts could be used to combat villains, from hooligans and rapacious robbers to "the revolver fiend' ${ }^{103}$. Respected book titles included a work by the featherweight wrestling champion and jujitsuka, Percy Longhurst, entitled Jiu-Jitsu and Other Methods of Self-Defence (1906); W. H. Collingridge's Tricks of Self-Defence (1914) and Ju-Jitsu: What It Really Is (1904) by magazine editor and music hall wrestler, William Bankier. Jujitsu even appeared in Robert Baden-Powell's seminal text-book on the making of British manliness, Scouting for Boys (1908), demonstrating how

\footnotetext{
98 Fry (1904, p. 199).

99 Uyenishi (1906, p. 14).

100 Uyenishi (1906, p. 7).

101 Tosh $(2004$, p. 45).

102 Uyenishi (1906, p. 8).

103 Anonymous (1909b, p. 127).
} 


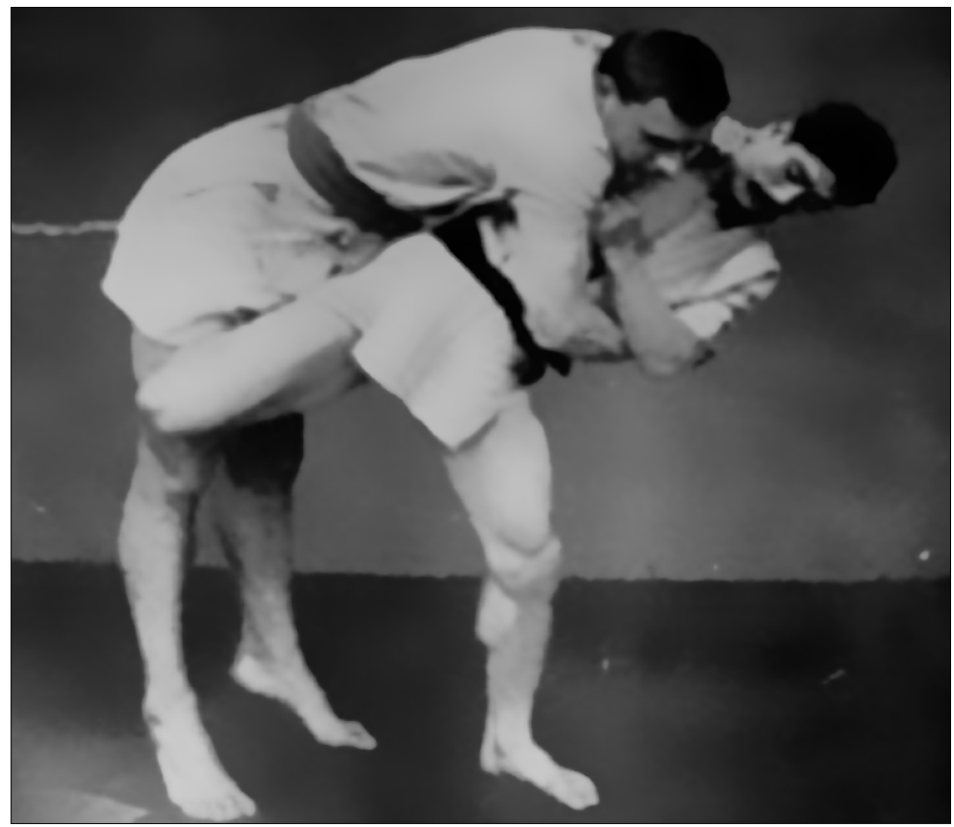

Figure 4: Uyenishi (1906).

non-hegemonic and 'foreign' masculinity was used as a reference point in the creation of British masculinity.

Britain was not the only European country to foster an interest in martial arts, although London was the world-centre, especially as experts from across the globe were drawn to the Bartitsu Club. Aaron Freundschuh has recently shown that there was a vibrant culture of self-defence in Paris of the Belle Époque. While he links the proliferation of the martial arts industry to the changing needs of a growing city, he has focused almost exclusively on primary and secondary sources relating to France and, in the process, has omitted not only scholarship on Barton-Wright but also secondary works on crime and aggression. Consequently, Freundschuh does not consider the links between self-defence and changing attitudes towards interpersonal violence.

A prolific writer of self-defence manuals, Émile André had introduced L'art de se défendre dans la rue (1899) to Paris in the same year that Bartitsu appeared in PM. Like Barton-Wright, André created his own brand of martial art. In 100 Façons de se défendre dans la rue sans armes (1905) André remarks that unlike English boxing, his interpretation of French kickboxing embraces the punching techniques of English boxing and the kicking styles of la savate. The illustrations in André's 100 façons de se défendre dans la rue sans armes imply that it was not the Frenchman per se who was violent but rather, the 'Apache'. Indeed, André's illustrations depict the middleclass Parisian being assaulted by ruffians and at other times defending himself with vigour against a knife attack. Therefore, the topic of a street mugging offered an opportunity to exhibit class and French national identity [Figure 5].

Mirroring Doyle's use of Bartitsu, Maurice Leblanc's celebrated criminal, Arsène Lupin, operates on the side of the law and maintains moral values using martial arts. 


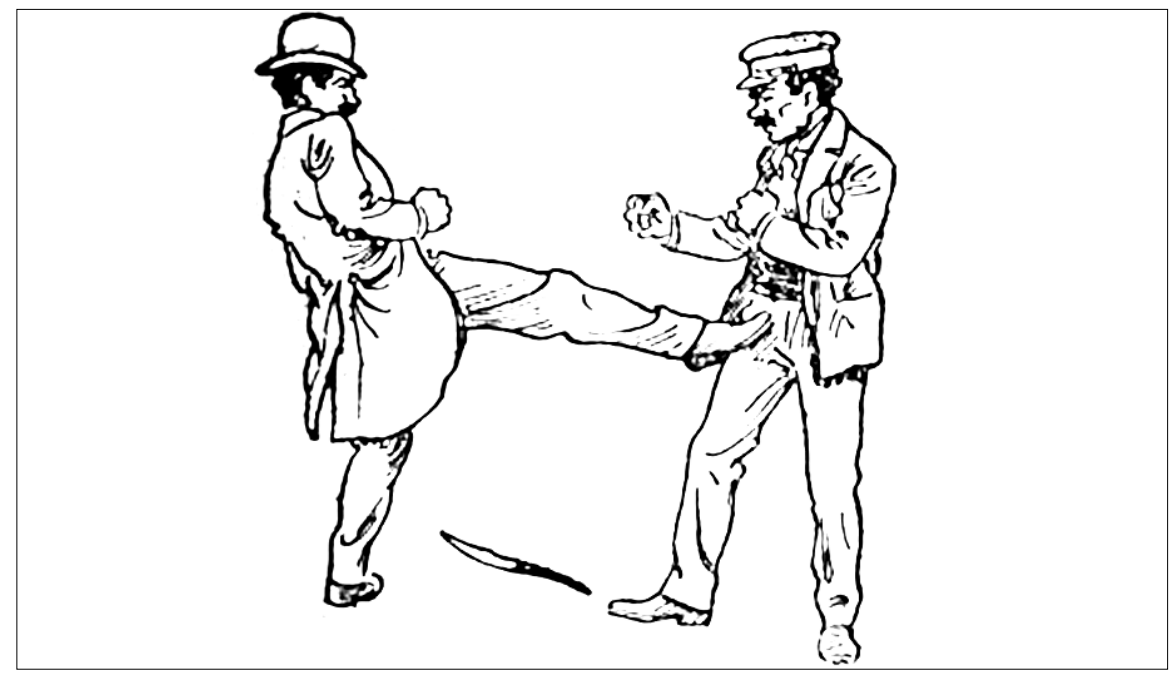

Figure 5: André (1905, p. 145).

In 'The Mysterious Passenger' (1907; hereafter 'TMP'), Lupin defends himself against a revolver- and knife-wielding murderer using a strike called the 'carotid hook ${ }^{104}$. Leblanc promotes the heroism of jujitsu to the French civilian by showing that the police were being trained in the art in Paris. The Prefecture of Police commenced ju-jitsu training in $1905^{105}$ and some evidence suggests that the Metropolitan Police were taught ju-jitsu during this time ${ }^{106}$. When his nemesis, Inspector Ganimard, attempts to throttle him, Lupin retaliates confidently with jujitsu:

The struggle was short. Arsène Lupin hardly made a movement in defence and Ganimard let go as promptly as he had attacked. His right arm hung numbed and lifeless by his side... "If they taught you jiu-jitsu at the Quai des Orfèvres", said Lupin, "you would know that they call this movement udi-shi-ghi in Japanese". [...] "Another second and I should have broken your arm..."

If London was the home of Bartitsu, then Leblanc nevertheless placed Paris on the martial arts map.

\section{SELF-DEFENCE: RECONFIGURING THE SPATIAL ORDER}

The newly fashionable, minimally aggressive forms of self-defence of the 1900s opened urban spaces and created avenues for the possibility of masculine self-

\footnotetext{
104 Leblanc (1907, p. 192).

105 Freundschuh (2006, p. 429).

106 In conversation with Clive Emsley. See Collingridge (1914, title page); Anonymous (1909a) and Sylvia Pankhurst: "We have not yet made ourselves a match for the police, and we have got to do it. The police know jiu-jitsu. [...] Women should practice (sic) it as well as the men", New York Times, 20 August 1913.

107 Leblanc (1909, p. 156).
} 
expression along accepted cultural lines. Michel de Certeau relates urban walking to speech, arguing that the act of strolling is dictated by the structure of the city, and, as with language, boundaries can be negotiated resulting in shifts in meaning, changes in direction. He writes: 'Charlie Chaplin multiplies the possibilities of his cane; he does other things with the same thing and he goes beyond the limits that the determinants of the object set on its utilization' ${ }^{108}$. So too, did Barton-Wright.

Judith Walkowitz refers briefly to Barton-Wright's two articles, 'Self-Defence with a Walking-Stick', dismissing them as examples of the types of extraordinary subjects, designed both to 'amuse' and 'instruct', in which $P M$ specialized $^{109}$. However, the articles are rich sources, emphasizing the link between masculine athleticism, material consumption and the vanquishing of cultural fears. Barton-Wright's walking-stick art (known as 'la canne') combined the attributes of utility, elegance and the visual performance of chivalry infused with romantic notions of duelling. As Donna T. Andrew shows, The Prisoner of Zenda was a twentieth-century fantasy of duelling and charts the middle-classes aversion to the sport ${ }^{110}$. Yet, the novel itself participated in a cultural fascination with an illegal way of settling honour disputes which had only a few decades earlier been eradicated. In The Sorrows of Satan the Devil, disguised as a foreign count, laments the demise of the sword duel:

\begin{abstract}
"There is no real use in this flimsy blade [...]. In old times, if a man insulted you, or insulted a woman you admired, out flashed a shining point of tempered Toledo steel that could lunge - so!" and he threw himself into a fencing attitude of incomparable grace and ease [...] But now [...] men [rely] no more on themselves for protection, but content to go about yelling 'Police! Police !' at the least threat of injury to their worthless persons." 111
\end{abstract}

He searches the metropolis for an individual to spurn him so that he may go to Heaven. The count tempts the narrator with traditional means of upholding honour which, as Wiener says, "were no longer considered manly by either state authorities or a growingly "respectable" public" ${ }^{112}$. However, the narrator is impressed by the count's performance.

The ordinary walking-stick could not be handled in the same way as a fencing sword or single-stick as it lacked a hilt so the stick had to be held in a different manner. A single-stick 'expert' such as Sherlock Holmes could have learnt the art although a complete beginner could easily acquire the skills ${ }^{113}$. A modern performance of Bartitsu given to the author by Tony Wolf and the Interpretation Department at the Royal Armouries, Leeds, confirms the impression that Barton-Wright's self-defence with the walking-stick is a controlled yet dynamic form of physical exposition ${ }^{114}$. It was claimed that Bartitsu promoted muscular flexibility. According to Barton-Wright, la canne was not only a 'useful and practical accomplishment' but

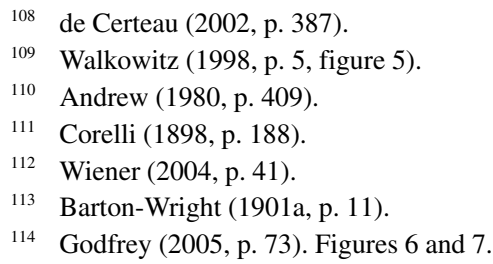




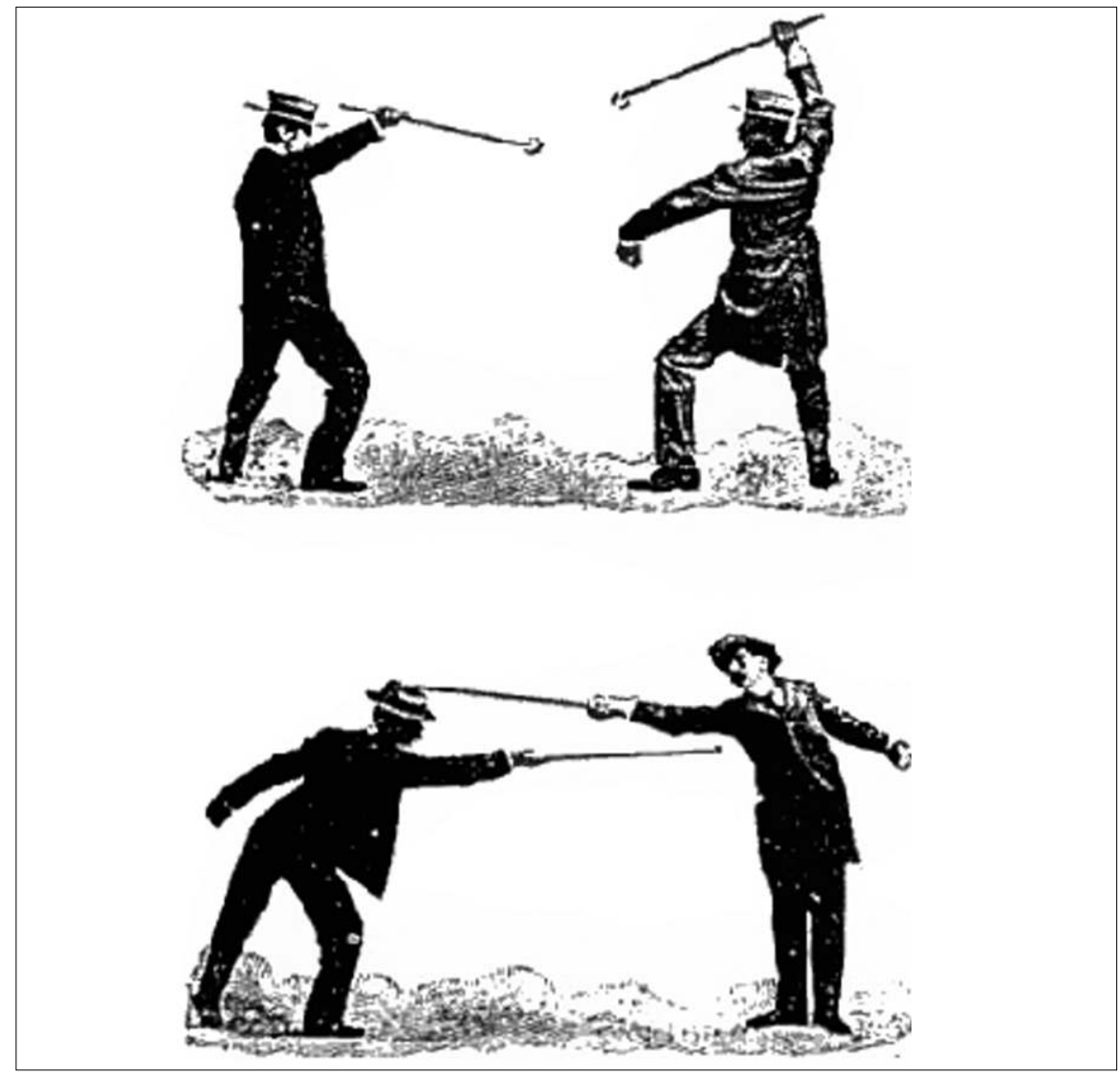

Figures 6 and 7: Barton-Wright (1901, p. 11).

also 'a most exhilarating and graceful exercise' ${ }^{115}$. The result conveys a sense of physical brilliance on the would-be Bartitsuka. As Phillip Mason argues, '[according to] the ethics of the public school [...] it was not the thing to try too hard. There was admiration for brilliance if it seemed to be effortless" ${ }^{116}$. Therefore, the selfdefence scenario inspired the ability to improvise in an unscripted and perilous situation and also evoked a physical reaction that looked visually striking and 'effortless'.

Barton-Wright credits the dashing Swiss maître d'armes, Pierre Vigny, as the inventor of la canne. He had founded his own method of hand-to-hand combat and opened a martial arts school in London in $1903^{117}$. Vigny explored the urban labyrinth and he was a self-confessed man about town, "fantastic of dress, with

\footnotetext{
115 Barton-Wright (1901b, p. 139).

116 Mason (1982, p. 142).

117 Wolf (2005, p. 110).
} 
exaggerated mannerisms, full of emotion, a brilliant winner, but a poor loser ${ }^{118}$. Just as he flaunted himself he also flouted the spatial order of the city, cutting and thrusting, breaking with his switch (a synonym for cane) across divisions, such as those between London's East and West. It is interesting to note the contradiction whereby in contrast to the man of blood, the 'reasonable man' learns Bartitsu as a non-violent means of self-defence but then seeks confrontation in order to exhibit his skills. As one journalist wrote of la canne: 'One serious drawback there is to all these attainments, and that is the desire, when one becomes proficient, to stroll down into the Hooligan quarters' 119 . Vigny's 'nightly excursions into the roughest of the rough quarters of Paris, Lyons, Marseilles, Naples, Genoa' offered him 'ample opportunities of pitting himself against men who robbed for a livelihood', who 'would commit a brutal assault for five francs, and a murder for twenty ${ }^{120}$. Engaging in his own epic quests, Vigny tested his art of walking-stick self-defence in 'gambling hell[s]' and 'drinking den[s]' against 'hostile mobs' and 'Hooligans' ${ }^{\text {'21 }}$. Barton-Wright himself had to decline a performance requested by Prince Edward, the Prince of Wales, due to a hand injury which he allegedly incurred whilst fighting street ruffians. Such pursuits certainly go beyond the need for self-defence; however, they can be interpreted as endeavours to articulate independence (from the need for police protection) and to extend the art of flâneuring into the realm of the physical. Like Chaplin, Barton-Wright reinterpreted the existing sartorial language of manliness - the suit, hat and cane. This is also implicit in Barton-Wright's choice of language. Building on the relationship between walking and language, the term 'switch', as it relates to walking, signifies a change in direction. Thus, when Barton-Wright and Vigny warded off 'savage' criminals on their urban adventures, they also etched a new idea of middle-class heroism with a sleight of hand.

\section{CONCLUSION}

Perceptions of threat in the late-nineteenth century were predicted on concerns over interpersonal violence but were also permeated by a multiplicity of apprehensions regarding the British male body. This examination of literary and cultural sources has demonstrated that the right to self-defence was indeed influenced by the disapproval of interpersonal violence. These last years of the nineteenth century were characterised by sharpening visions of imperial decline and were accompanied by an ever tightening control over the potentially destructive impulses of masculinity. Social explorers and writers alike located crime geographically, in the metropolis, but also found its roots in the mind and linked it to physical as well as moral degeneration. In this climate, self-defence signified more than an attempt to secure purse and person; it became a national duty to learn to how to defend oneself, albeit in the appropriate manner in order to keep both desperados and degeneration at bay. Although it was statistically unlikely that the ordinary city-dweller could become a victim of violent street crime, the encounter with violent criminals was nevertheless

\footnotetext{
118 Jewell (1904, p. 174).

119 Pall Mall Gazette, 23 Oct. 1900.

120 Jewell (1904, p. 174).

121 Jewell (1904, pp. 174-177).
} 
a legitimate danger. The tools employed by criminals were displayed for the public eye in museums but by contrast, the accoutrements of self-defence were employed stylishly by the assertive Bartitsuka and jujitsuka and were legitimate consumer items, markers of the owner's social standing. The Bartitsuka's use of these simple items defined him against the man of blood and as far as Barton-Wright and his many fashionable contemporaries were concerned, by the turn of the century the pistol should not only not be condoned but rendered passé. Bartitsu constituted an exotic mélange of fighting styles, fortified with 'traditional' British virtues. BartonWright's creation could be adapted to fit in with the mere act of strolling, with the anticipation of or encounter with crime. Martial arts were not only designed for use against physical threat, they prompted an imaginative response to the quotidian, an emotional and personalised engagement with the landscape of the city.

Emelyne Godfrey
Flat 183
Pierpoint Building
16 Westferry Road
UK - E14 8NQ
scruffybread@googlemail.com

\section{REFERENCES}

Adler, J., Shoot to Kill: The Use of Deadly Force by the Chicago Police, 1875-1920, Journal of Interdisciplinary History, 2007, 38, 2, pp. 233-254.

Allanson-Winn, R. G., Phillipps-Wolley, C., Broad-Sword and Single-Stick, London, George Bell and Sons, 1890.

Allen, D. W., Young England: Muscular Christianity and the Politics of the Body in 'Tom Brown's Schooldays', in Hall, D. E. (ed.), Muscular Christianity: Embodying the Victorian Age, Cambridge, Cambridge University Press, 1994, pp. 114-132.

Andre, É., 100 façons de se défendre dans la rue sans armes, Paris, Ernest Flammarion, 1905.

Andrew, D., The Code of Honour and its Critics: The Opposition to Duelling in England, 1700-1850, Social History, 1980, 5, 3, pp. 409-434.

Anonymous, Another Chamber of Horrors: The Police Museum of Scotland Yard, Black and White Budget, 1900, 4, pp. 138-139.

Anonymous, Crime and Criminals: Burglars and Burgling, Strand, 1894, 7, pp. 273-284.

Anonymous, Crime and Criminals: Dynamite and Dynamiters, Strand, 1894, 7, pp. 118-132.

Anonymous, Ju-jutsuffragettes, A New Terror for the London Police, Health and Strength, 24 April 1909, 6, p. 421.

Anonymous, The Revolver Fiend Abroad and How to Baffle Him, Health and Strength, 6 February 1909, 6, p. 127.

Archbold's Pleading and Evidence and Criminal Cases, London, H. Sweet and Sons, 1886. Barton-Wright, E. W., How to Pose as a Strong Man, Pearson's Magazine, 1899a, 7, pp. 59-66.

Barton-Wright, E. W., The New Art of Self Defence: How a Man may Defend Himself Against Every Form of Attack [Part 1], Pearson's Magazine, 1899b, 7, pp. 268-275.

Barton-Wright, E. W., The New Art of Self-Defence [Part 2], Pearson's Magazine, 1899c, 7, pp. 402-410. 
Barton-Wright, E. W., Self-Defence with a Walking-Stick: The Different Methods of Defending Oneself with a Walking-Stick or Umbrella when Attacked under Unequal Conditions [Part 1], Pearson's Magazine, 1901a, 11, pp. 11-20.

Barton-Wright, E. W., Self-Defence with a Walking-Stick: The Different Methods of Defending Oneself with a Walking-Stick or Umbrella when Attacked under Unequal Conditions [Part 2], Pearson's Magazine, 1901b, 11, pp. 130-139.

Boddice, R., Manliness and the 'Morality of Field Sports': E. A. Freeman and Anthony Trollope, 1869-71, The Historian, 2008, 1, 70, pp. 1-29.

Bondeson, J., The London Monster: A Sanguinary Tale, Cambridge, University of Pennsylvania Press/Da Capo Press, 2002.

Bowen, R., Further Lessons in Baritsu, The Ritual Bi-Annual Review: The Northern Musgraves Sherlock Holmes Society, 1997, 20, pp. 22-26.

Cantlie, J., Degeneration Amongst Londoners, London, Field and Tuer, 1885 ; repr. Lee Jackson <http: www.victorianlondon.org > [accessed 8 June 2009].

de Certeau, M., Walking in the City, in Bridge? G., Watson S., The Blackwell City Reader, Oxford, Blackwell, 2002, pp. 383-392.

Collingridge, W. H., Tricks of Self-Defence, London, Health and Strength Limited, 1914.

Connell, R. W., Masculinities, Cambridge, Polity, 2006 (rev. edn).

Corelli, M., The Sorrows of Satan, Or the Experience of One Geoffrey Tempest, Millionaire, London, Methuen and Co, 1898.

Davies, A., Youth Gangs, Masculinity and Violence in Late Victorian Manchester and Salford, Journal of Social History, 1998, 32, pp. 349-369.

Dennis, R., Cities in Modernity: Representations and Productions of Metropolitan Space, 1840-1930, Cambridge, Cambridge University Press, 2008.

Dike, C., Cane Curiosa: From Gun to Gadget, Geneva, Les Éditions de l'Amateur, 1983.

Doyle, A.C., The Penguin Complete Sherlock Holmes, London, Penguin, 1981.

Egan, P., Every Gentleman's Manual: A Lecture on the Art of Self-Defence, London, Flintoff, 1851.

Eissler, M., A Handbook of Modern Explosives: Being a Practical Treatise on the Manufacture and Application of Dynamite, Gun-Cotton, Nitro-Glycerine, and other Explosive Compounds, Including the Manufacture of Collodion-Cotton, London, Crosby Lockwood and Son, 1890.

Emsley, C., Crime and Society in England, 1750-1900, London, Longman/Pearson, 2005 (rev. edn).

Emsley, C., The English Police: A Political and Social History, London, Longman/Pearson, 1996.

Emsley, C., Hard Men: The English and Violence Since 1750, London, Hambledon and London, 2005.

Emsley, C., 'The Thump of Wood on a Swede Turnip': Police Violence in NineteenthCentury England, Criminal Justice History, 1985, 6, pp. 125-149.

Eyffinger, A., The 1899 Hague Peace Conference: 'The Parliament of Man, the Federation of the World', The Hague, Kluwer Law International, 1999.

Freundschuh, A., "New Sport" in the Street: Self-Defence, Security and Space in Belle Époque Paris, French History, 2006, 20, pp. 424-441.

Fry, E., The Peril of the East, Health and Strength, 1904, 9, pp. 198-200.

Gay, P., The Cultivation of Hatred in The Bourgeois Experience: Victoria to Freud, London, Harper Collins, 1994, 5 vols (3). 
Gibson, M., Green, R. L. (Eds), The Unknown Conan Doyle: Letters to the Press, London, Secker and Warburg, 1986.

Gilbert, W. S., London Characters and the Humorous Side of London Life (c.1871) [http://www.victorianweb.org/books/mcdonnell/streets1.html], accessed 6 June 2009.

Godfrey, E., Bartitsu: A Martial Art Tailor-Made for the Late-Victorian and Edwardian English Gentleman, The Bartitsu Compendium: Volume 1: History and Canonical Syllabus, Tony Wolf (Ed.), United States, Lulu.com, 2005, pp. 69-76.

Greenwood, C., Firearms Control: A Study of Armed Crime and Firearms Control in England and Wales, London, Routledge and Kegan Paul, 1972.

Harrison, G. C. Jr., The Anti-Garotter, The Gun Report, 1956, 2, p. 22.

Hitchens, P., A Brief History of Crime: The Decline of Order, Justice and Liberty in England, London, Atlantic Books, 2003.

Hughes, T., Tom Brown's Schooldays: By an Old Boy, 1857; repr. Oxford, Oxford University Press, 1999.

Jewell, J., St. A., The Gymnasiums of London: Pierre Vigny's, Health and Strength, 1904, 7, pp. 173-177.

Kidd, A., Nicholls D., (eds), Gender, Civic Culture and Consumerism : Middle-Class Identity in Britain 1800-1940, Manchester University Press, Manchester, 1999.

Leblanc, M., Arsène Lupin: Gentleman Cambrioleur, Paris, Pierre Lafitte and Co., 1907.

Leblanc, M., The Exploits of Arsène Lupin trans. by Alexander Teixeira de Mattos, London, Cassell and Co., 1909.

Longhurst, P., Jiu-Jitsu and Other Methods of Self-Defence, London, L. Upcott Gill, 1906.

Malcolm, J. L., Guns and Violence: The English Experience, London, Harvard University Press, 2002.

Marsh, R., Mandragora, from Judith Lee: The Experiences of a Lip-Reader, Strand, 1912, 44, pp. 176-186.

Mason, P., The English Gentleman: The Rise and Fall of an Ideal, London, André Deutsch, 1982.

Metcalfe, E., Branding A Thief, Sandow's Magazine, 1900, 4, pp. 443-446.

Newton, A. J., Boxing, London, C. Arthur Pearson, 1910.

Nugent, M., Barton-Wright and his Japanese Wrestlers: A Man and his Method, Health and Strength, 1901, 3, pp. 336-341.

Paterson, J., Commentaries on the Liberty of the Subject and Laws of England Relating to the Security of the Person, London, Macmillan and Co., 1877, 2 vols (1).

Pearson, G., Hooligan: A History of Respectable Fears, London, Macmillan Press, 1983.

R v. Rose, 15 Cox CC 540 (Assizes), 1884.

Rotundo, A. E., Learning about Manhood: Gender Ideals and the Middle-Class Family in Nineteenth-Century America, in Mangan, J. A., Walvin, J., Manliness and Morality: Middle-Class Masculinity in Britain and America, 1800-1940, Manchester, Manchester University Press, 1987, pp. 35-51.

Sennett, R., The Conscience of the Eye: The Design and Social Life of Cities, London, Faber and Faber, 1991.

Shipley, S., Tom Causer of Bermondsey: A Boxer Hero of the 1890s, History Workshop, 1983, Spring 15, pp. 28-59.

Simmel, G., The Metropolis and Mental Life, in Levine, D. N., On Individuality and Social Forms: Selected Writings of Georg Simmel, Chicago, University of Chicago Press, pp. 324-339. 
Simpson, A., Dandelions on the Field of Honor: Duelling, the Middle Classes, and the Law in Nineteenth-Century England, Criminal Justice History, 1988, 9, pp. 99-155.

Sindall, R., Street Violence in the Nineteenth-Century: Media Panic or Real Danger?, Leicester, Leicester University Press, 1990.

Stephen, J. F., A General View of the Criminal Law of England, Macmillan and Co, New York, 1890.

Strachan, J., Poets and Pugilists, History Today, 2009, January, pp. 17-23.

Taylor, I., Taylor A., The Assassin's Cloak: An Anthology of the World's Greatest Diarists, Edinburgh, Canongate, 2000.

Tindal, M., Self Protection on a Cycle, Pearson's Magazine, 1901, 11, pp. 425-431.

Torrese, D. M., Firearms in the Canon: The Guns of Sherlock Holmes and John H. Watson, Baker Street Journal : An Irregular Quarterly of Sherlockiana, 1992, 42, 3, pp. 154-518.

Tosh, J., A Man's Place: Masculinity and the Middle-Class Home in Victorian England, Yale University Press, 1999.

Tosh, J., Hegemonic Masculinity and the History of Gender, in Dudink, S., Hagemann, K., Tosh J., Masculinities in Politics and War: Gendering Modern History, Manchester, Manchester University Press, 2004, pp. 41-60.

Trollope, A., Phineas Redux, 1874; repr. Oxford, Oxford World's Classics, 2000, 2 vols (2).

Uyenishi, S. K., The Text-Book of Ju-Jitsu As Practised in Japan, London, Health and Strength, 1906.

Walkowitz, J., City of Dreadful Delight: Narratives of Sexual Danger in Late-Victorian London, London, Virago, 1992.

Walkowitz, J., The Indian Woman, the Flower Girl, and the Jew: Photojournalism in Edwardian London, Victorian Studies, 1998/1999, 42, pp. 3-36.

Wells, H. G., 'Zoological Retrogression', 1891. Reprinted in Ledger, S., Luckhurst, R., The fin de siècle: A Reader in Cultural History, 1880-1900, Oxford, Oxford University Press, 2000, pp. 5-12.

Wells, H. G., The War of the Worlds, 1898; repr. London, Everyman, 1993.

White, J., London in the Twentieth Century: A City and its People, London, Vintage, 2008.

Wiener, M., New Women Vs. Old Men? Sexual Danger and 'Social Narratives' in LaterVictorian England, Journal of Victorian culture, 1997, 2, pp. 302-309.

Wiener, M., Alice Arden to Bill Sikes: Changing Nightmares of Intimate Violence in England, 1558-1869, Journal of British studies, 2001, 40, pp. 184-213.

Wiener, M., Men of Blood: Violence, Manliness and Criminal Justice in Victorian England, Cambridge, Cambridge University Press, 2004.

Wilkinson, F., Those Entrusted With Arms: A History of the Police, Post, Customs and Private Use of Weapons in Britain, Leeds, Royal Armouries/Greenhill Books, 2002.

Winant, L., Firearms Curiosa, New York, Greenberg, 1955.

Wolf, 'Masters of Antagonistics' The Bartitsu Compendium: Volume 1: History and Canonical Syllabus, Tony Wolf (Ed.), United States, Lulu.com, 2005, pp. 105-111.

Wood, J. C., 'A Useful Savagery': The Invention of Violence in Nineteenth-Century England' Journal of Victorian Culture, 2004, 9, 1, pp. 22-42.

Wood, J. C., Violence and Crime in Nineteenth-Century England: The Shadow of Our Refinement, London, Routledge, 2004.

Wood, J. C., Self-Policing and the Policing of the Self: Violence, Protection and the Civilising Bargain in Britain, Crime, Histoire \& Sociétés/Crime, History and Societies, 2003, 7 , 1 , pp. 109-128. 